DOI: https://doi.org/10.31392/NZ-npu-144.2019.12

УДК 37.371.373.29

Іванова В. В.

\title{
СТРУКТУРА СИСТЕМИ ДОШКІЛЬНОЇ ОСВІТИ У ВЕЛИКІЙ БРИТАНІЇ ТА КРАЇНАХ ЄС (НА ПРИКЛАДІ ФРАНЦІї, НІМЕЧЧИНИ, ФІНЛЯНДІї, ПОЛЬЩІ, ШВЕЙЦАРІї)
}

У статті розглянуто особливості структури сучасної доикільної освіти у Великій Британії та країнах ЄС (Франції, Німеччині, Фінляндії, Польщі, Швейиарії).

Поряд з особливостями системи дошкільної освіти в різних країнах виявлено і спільні ознаки.

3'ясовані різні підходи до підготовки дітей до школи у різних краӥнах (використання різних форм інтеграиії дитячих садків і початкових класів; виконання функиї передшкільного ступеня: підготовчі групи або класи при дитячих садках чи при початкових школах (у Німеччині); передикільні групи для дітей (у Фінляндіï, Даніі); нульові класи при школах або підготовчі групи в дитячих садках (у Польщі); фінансування відбувається по-різному: в держсавних дитячих дошкільних закладах навчання $і$ виховання безоплатне (Велика Британія (частково), Німеччина). У Німеччині, крім того, законом гарантовану підтримку альтернативних дошкільних закладів, крім приватних. В республіиі Польщі, у Фінляндії, Швеймарії держсава приділяє багато уваги дошкільним навчальним закладам.

В країнах ЄС при здійсненні виховання і навчання в дошкільних навчальних закладах застосовуються підходи: диференційований, індивідуальний, творчий; використовується система Монтессорі.

Ключові слова: структура системи дошкільної освіти, Велика Британія, краӥни СС, спільні ознаки, різні підходи до підготовки дітей до школи у різних країнах, підходи.

Україна скеровує свій напрям в європейське наукове співтовариство, що призводить до необхідності конкурентноспроможності вищої освіти на світовому ринку. Тому наявні суттєві зміни та вдосконалення дошкільної освіти, пошук ефективних шляхів здійснення якісних виховних і навчальних послуг, модернізації змісту дошкільної освіти. Дослідження скеровано на з'ясування особливостей структури сучасної дошкільної освіти у Великій Британії та країнах ЄС (Франції, Німеччині, Фінляндії, Польщі, Швейцарії).

Увага на досвід цих країн пояснюється тим, що ці країни - одні з найбільш розвинених, вони мають суттєві напрацювання в організації дошкільної системи освіти, постійно вдосконалюють рівень підготовки майбутніх фахівців.

Стосовно організації сучасної дошкільної освіти у країнах Європейського Союзу, то ця проблема постійно знаходиться в полі зору вітчизняних науковців. Зокрема, проблеми рефрормування вищої освіти Великої Британії та Європейського регіону $\epsilon$ темою досліджень вітчизняних і зарубіжних компаративістів (Н. Авшенюк, Ф. Богуш, Б. Вульфссон, О. Зима, ..Корсак, В. Кремень, О. Матвієнко, Н. Ничкало, Л. Пуховська, С. Сажник, А. Сбруєва, Т. Степанова та ін.).

Метою статті $є$ розгляд теоретичних засад упровадження англомовної освіти у початкову школу в сучасній Україні.

Для досягнення поставленої мети використано такі методи дослідження: теоретичні (аналіз філософської, педагогічної, психологічної літератури), що дає змогу обґрунтувати вихідні положення дослідження; інтерпретаційно- 
аналітичний метод, на основі якого вивчаються джерела із застосуванням синтезу, аналізу, систематизації та узагальнення.

Розглянемо особливості структури сучасної дошкільної освіти у Великій Британії.

Дошкілля у Великій Британії пройшло шлях розвитку від закладів суспільного догляду дітей із незаможних родин до сучасних різноманітних типів дошкільних закладів, що забезпечують диференційований підхід до виховання дітей. Слід зазначити, що таких закладів у Великій Британії недостатньо для того, щоб забезпечити доглядом усіх дітей до школи, навчання у якій починається з 5 років. Основні типи дошкільних закладів: муніципальні та приватні денні ясла, ясельні школи, ясельні класи, ігрові групи, клуби матері і дитини, “групи можливостей”. За змістом роботи їх можна об'єднати в три групи:

1) денні ясла - забезпечують належний догляд за дітьми;

2) ясельні класи і школи - заклади інтелектуального розвитку, підготовки до школи;

3) ігрові групи, клуби матері та дитини, групи “можливостей", які організовуються батьками, - гарантують найвищий рівень всебічного виховання [1; 2].

Муніципальні денні ясла відкриваються місцевими органами влади для дітей віком від кількох місяців до 4-5 років. Ці заклади досить поширені, вони працюють впродовж року з 8 до 18 год., оскільки призначені для виховання дітей працюючих батьків з невисоким рівнем прибутків, які потребують послуг закладів суспільного дошкільного виховання. Водночас з державною системою (93\%) фрункціонує й приватна (7\%).

Приватні денні ясла створюються різними приватними установами та особами, благодійними товариствами, релігійними організаціями тощо. До таких закладів належать:

- церковнообщинні денні ясла; ясла, які відкривають для своїх працівників фабрики, компанії, корпорації, банки;

- комерційні ясла;

- кооперативні ясла;

- ясла психолого-педагогічного профрілю при науково-дослідних центрах. Їх мета надавати матерям, які мають малих дітей, кілька годин вільного часу на день.

У Великій Британії відпустка по догляду за дитиною триває всього 9 місяців. Якщо мати не бажає втратити робоче місце, вона має найняти няню або скористатися послугами приватних ясел - і те, і інше коштує недешево: від 11 до 20 тисяч фрунтів на рік. Один день перебування у лондонському приватному садку коштує близько 80 фунтів. Приймають у такі заклади 3 3 місяців [3].

У країні є велика кількість приватних вихователів, які за бажанням батьків працюють із дітьми віком від народження до 5 років упродовж усього робочого дня. Відтак забезпечується І ступінь освіти: 4-7 річні дошкільники та 7-11 річні 
діти - початкова школа.

Безоплатні муніципальні ясельні школи і класи для дітей 3-5 років дуже популярні у Великій Британії. Існують навіть черги з тих, хто бажає влаштувати до них своїх дітей [2].

Починаючи з трирічного віку дитина може перебувати в державному дитячому садку за рахунок держави упродовж 15 годин на тиждень. Державний дитсадок являє собою прикріплений до школи своєрідний “стартовий майданчик”.

Стандартний алгоритм влаштування дитини до державного садку при школі починається з подачі батьками заяви до самої школи, розташованої в їх районі (borough). Заява подається того року, коли дитина досягає трирічного віку, приблизно в лютому.

На безкоштовний повний день мають право лише пільгові категорії громадян європейського походження.

У 4 роки малюки йдуть до школи, найчастіше до тієї, до якої прикріплено їхній садок, щоб пройти річний підготовчий курс - "reception”. Ще через рік вони стануть школярами.

Багато речей, звичайних для англійських дитсадків, здаються нам дивними. Наприклад, для дітей, яким виповнилося більше року, в дитсадках відсутня тиха година. Немовлята сплять у ліжках, але не завжди у кожної дитини $є$ своє ліжко. Роздягатися на час тихої години не прийнято - діти сплять у тому, в чому гралися. Якщо, влаштовуючи малюка до садку, батьки підкреслять, що дитині необхідний денний сон, йому нададуть килимок у ігровій кімнаті і пояснять, що на ньому в будь-який час можна приляти і відпочити.

У цій же ігровій кімнаті малеча приймає їжу. Гарячі обіди, як і в багатьох інших дитсадках світу, тут не надаються. Харчування найчастіше обмежене запеченими або вареними овочами, соками, печивом. Зустрічаються в меню також бургери й картопля фрі. Деякі дорогі приватні садки мають у своєму розпорядженні власні кафе, які надають малюкам здорову органічну їжу, але перебування в них коштує дорого [3].

Хороший варіант для тих батьків, чия дитина з якихось причин не відвідує дитячий садок - ігрові групи (playgroups). Велика частина дітей у них - малюки від 2 до 3 років. Вони приходять до групи з батьками, граються й спілкуються. Персонал складається з медсестер і волонтерів - кваліфікованих педагогів тут зустріти складно. Такі групи - не державні організації, й часто вони існують на благодійних засадах.

Головна мета ігрових груп - соціалізація дитини перед вступом до дитячого садку або школи [3].

Ігрові групи - найпоширеніший тип дошкільних закладів, об'єднаних в асоціацію дошкільних ігрових груп, що фрінансуються 3 кількох джерел: частково державою, благодійницькими фондами, значною мірою - батьками. Тут виховується більше третини дітей віком 2-3 років. У групі від 6 до 40 малят, працюють такі групи 2-3 години від двох до п'яти днів на тиждень. Керівники 
ігрових груп (зазвичай це матері вихованців) проходять спеціальну психологопедагогічну підготовку.

Лікарняні ігрові групи призначені для виховання дітей, які перебувають на лікуванні.

"Групи можливостей” призначені для виховання дітей з відхиленнями у розвитку. Вони працюють за зразком ігрових груп із значно меншою кількістю дітей, використовуючи спеціальний ігровий і навчальний матеріал [2].

У клубах матері й дитини обов'язковою $є$ присутність матері впродовж всього перебування там дитини.

Структура дошкільного виховання в Англії є досить гнучкою і охоплює різні типи закладів, що конкурують у боротьбі за ресурси та вихованців. Батьки намагаються навчати своїх дітей у закладах поза системою державної освіти, у приватних чи в незалежних (авторських) дитячих садках. Така тенденція в країні чітко вимальовується з 1997 р. після об'єднання міністерств зайнятості населення й освіти. Англія ввійшла в XXI ст. з системою дошкільного виховання, в якій віддзеркалено не лише ії минуле, а й ті динамічні зміни, що відбулися в XX ст. в освіті країни загалом [2].

Ясельні центри - це об'єднані денні ясла і ясельні школи, досить незначні за кількістю. Ясельні класи організовуються при початковій школі для розумового, фізичного, морального, естетичного і трудового розвитку дитини, формування індивідуальності.

У Великобританії в приміщенні "ясельної школи" знаходиться надзвичайно велика кількість різноманітного обладнання та матеріалів: великі мольберти з прикріпленими до них аркушами паперу, набори великих банок 3 фарбами, пензликів, крейди; верстак 3 лещатами, інструментами і матеріалами (молотки, кліщі, цвяхи, пили, шматки дерева); ванна з водою, в якій знаходяться плаваючі іграшки і специфічні "водяні іграшки" типу водяних млинів; пісочниці з сухим і мокрим піском і безліч іншого матеріалу, який сприяє розумовому і фрізичному розвитку дитини. У дитячих садах простір організовано відповідно до "відкритого плану". Всі кімнати відокремлюються одна від іншої перегородками, у дітей $є$ можливість вільно пересуватися по всьому дитячому садку. У приміщенні розташовані стелажі для книг та іграшок, столи з настільними іграми, добре оснащені куточки для ігор з піском і водою, зони конструктивно-будівельних ігор. У дітей $є$ можливість пограти на піаніно або позайматися на комп'ютері. У приміщенні виділяється тиха зона, в якій діти можуть відпочити, розслабитися. Освітнє середовище повинно забезпечувати дітям можливість самостійно вибирати і здійснювати будь-яку привабливу для дітей діяльність [1;4].

Отже, аналіз структури системи дошкільної освіти у Великій Британії свідчить, що для цієї країни характерні такі типи дошкільних закладів:

- денні ясла;

- ясельні класи та ясельні школи;

- ігрові групи;

- групи можливостей. 
Ясельні школи та класи (державні) для дітей 3-5 років частково безоплатні, ігрові групи (2-3 роки) фрінансуються з різних джерел. Поряд 3 державними закладами функціонує і приватна дошкільна освіта; до навчання і виховання дошкільників застосовується диференційований підхід; до школи діти готуються в дитячих садках, проходячи підготовчий курс.

Нами зроблено аналіз моделей структури сучасної дошкільної системи освіти у Великій Британії та інших країнах Європейського союзу.

Моделі організації дошкільної освіти в системі неперервної освіти у розглянутих країнах Європейського союзу (Великої Британії, Франції, Німеччини, Польщі, Швейцарії, Фінляндії) мають свої особливості та власний передовий досвід з проблеми організації дошкільної освіти. Зокрема, державою у Великій Британії забезпечується 93\% системи дошкільної освіти і лише 7\% існує в країні приватних дошкільних закладів; для Франції характерним $€$ наявність материнської школи, навчання дітей у материнській і початковій школах здійснюється одним педагогом, що свідчить про тісний зв'язок між дошкільним і початковим навчанням; у Німеччині виконання державних функцій в галузі дошкільної освіти, відповідно до конституції країни, покладається на автономні землі країни; особливістю дошкільного виховання у Фінляндії є тісний зв'язок держави із сім'єю; у Данії значна частина вихователів - чоловіки, що має особливе значення для дітей з неповних сімей, де є лише мати; особливістю системи дошкільної освіти у Швейцарії $€$ існування двох концепцій виховання дошкільнят.

Поряд з особливостями системи дошкільної освіти в різних країнах виявлено і спільні ознаки. Так, дошкільна освіта являє собою первинну ланку єдиної системи виховання і навчання, якою опікуються місцеві органи влади, різні підприємства, релігійні і громадські організації, приватні особи. У більшості країн функціонують дитячі ясла, різного роду дитячі садки з різною тривалістю роботи та різною наповнюваність і різним віком дітей, ігрові майданчики. 3 названих дитячих установах відповідно до програм навчання i виховання здійснюється навчання, а також і виховання, метою якого $є$ гармонійний розвиток дітей, формування навичок життя в суспільстві. В більшості країн ЄС функціонують такі типи дошкільних закладів як цілодобові інтернати для здорових дітей віком від 3 до 6 років або для дітей з проблемами здоров'я і розвитку.

Різні країни по-різному підходять до підготовки дітей до школи:

- використання різних форм інтеграції дитячих садків і початкових класів. Зокрема, старша група материнської школи (4-5 років) у Франції сполучена 3 першим роком навчання у початковій школі; у Швейцарії організовані комплекси: “дитячий садок-школа"; Виконання функції передшкільного ступеня: підготовчі групи або класи при дитячих садках чи при початкових школах (у Німеччині); передшкільні групи для дітей (у Фінляндії, Данії); нульові класи при школах або підготовчі групи в дитячих садках (у Польщі).

Що стосується фрінансування дошкільної системи освіти в країнах ЄС, то, зазначимо, що фінансування відбувається по-різному: в державних дитячих 
дошкільних закладах навчання і виховання безоплатне (Велика Британія (частково), Німеччина). У Німеччині, крім того, законом гарантовану підтримку альтернативних дошкільних закладів, крім приватних. В республіці Польщі, у Фінляндії, Швейцарії держава приділяє багато уваги дошкільним навчальним закладам.

Ми зазначаємо, що в країнах ЄС при здійсненні виховання і навчання в дошкільних навчальних закладах здійснюються переважно підходи: диференційований, індивідуальний, творчий, використовується система Монтессорі.

Висновки і перспективи подальших наукових досліджень 3 означеної проблеми. Розглянуто особливості структури сучасної дошкільної освіти у Великій Британії.

Поряд з особливостями системи дошкільної освіти в різних країнах виявлено і спільні ознаки (дошкільна освіта являє собою первинну ланку єдиної системи виховання і навчання, якою опікуються місцеві органи влади, різні підприємства, релігійні і громадські організації, приватні особи; у більшості країн функціонують дитячі ясла, різного роду дитячі садки з різною тривалістю роботи та різною наповнюваність і різним віком дітей, ігрові майданчики; у дитячих установах відповідно до програм навчання і виховання здійснюється навчання і виховання, метою якого є гармонійний розвиток дітей, формування навичок життя в суспільстві; функціонують такі типи дошкільних закладів як цілодобові інтернати для здорових дітей віком від 3 до 6 років або для дітей 3 проблемами здоров'я і розвитку).

3'ясовані різні підходи до підготовки дітей до школи у різних країнах (використання різних форм інтеграції дитячих садків і початкових класів; виконання функції передшкільного ступеня: підготовчі групи або класи при дитячих садках чи при початкових школах (у Німеччині); передшкільні групи для дітей (у Фінляндії, Данії); нульові класи при школах або підготовчі групи в дитячих садках (у Польщі); фрінансування відбувається по-різному: в державних дитячих дошкільних закладах навчання і виховання безоплатне (Велика Британія (частково), Німеччина). У Німеччині, крім того, законом гарантовану підтримку альтернативних дошкільних закладів, крім приватних. В республіці Польщі, у Фінляндії, Швейцарії держава приділяє багато уваги дошкільним навчальним закладам.

У країнах ЄС при здійсненні виховання і навчання в дошкільних навчальних закладах здійснюються переважно підходи: диференційований, індивідуальний, творчий, використовується система Монтессорі.

Перспективи подальших наукових досліджень з означеної проблеми полягатимуть у розкритті особливостей системи дошкільної освіти у Великій Британії та вивченні досвіду підготовки фахівців з предшкільної освіти.

\section{Використана література:}

1. Сазонова Д. С., Зебзеева В. А. Системы дошкольного образования за рубежом: их педагогический потенціал. Общчество и ичивилизацฺия в ХХІ веке: тенденцฺии и перспективы развития. 2014. № 812. C. 161-166. 
2. Дошкільне виховання за кордоном. URL: http://www.d-learn.pu.if.ua/data/users/8569/\%D0\%9B\% D0\%B5\%D0\%BA\%D1\%86\%D1\%96\%D1\%8F\%203.pdf

3. Зарубіжний досвід виховання дитини: дитячий садок у Великобританії. URL: https://firststep.com.ua/article/zarubiznii-dosvid-vihovanna-ditini-ditacii-sadok-u-velikobritanii

4. Козак Л. Сучасна дошкільна освіта: європейський досвід. Освітологічний дискурс. 2017. № 3-4 (18-19). С. 235-251.

\section{References:}

[1] Sazonova D. S., Zebzeeva V. A. Sistemy doshkolnogo obrazovaniya za rubezhom: ih pedagogicheskij potencial. Obshestvo i civilizaciya v HHI veke: tendencii i perspektivy razvitiya. 2014. № 8-12. S. 161-166.

[2] Doshkilne vykhovannia za kordonom. URL: http://www.d-learn.pu.if.ua/data/users/8569/\%D0\%9B\% D0\%B5\%D0\%BA\%D1\%86\%D1\%96\%D1\%8F\%203.pdf

[3] Zarubizhnyi dosvid vykhovannia dytyny: dytiachyi sadok u Velykobrytanii. URL: https://firststep.com.ua/article/zarubiznii-dosvid-vihovanna-ditini-ditacii-sadok-u-velikobritanii

[4] Kozak L. Suchasna doshkilna osvita: yevropeiskyi dosvid. Osvitolohichnyi dyskurs. 2017. № 3-4 (1819). S. 235-251.

ИвАнова В. В. Структура системы дошкольного образования в Великой Британии и странах ЕС (на примере Франции, Германии, Финляндии, Польши, Швейцарии).

В статье рассмотрены особенности структуры современного дошкольного образования в Великой Британии и странах ЕС (Франиии, Германии, Финляндии, Польше, Швейияарии).

Рядом с особенностяли системы доиккольного образования в разныхх странах вылявлены и обиче признаки.

Выясненные разные подходы к подготовке детей к иколе в разных странах (использования разных форм интеграции детских садиков и начальных классов; выполнение функиии предикольной степени: подготовительныле группы или классы при детских садиках или при начальных шкколах (в Германии); предикольные группь для детей (в Финлянди, Дании); нулевые классы при школах или подготовительные группы в детских садиках (в Польше); финансирования происходят по-разному: в государственных детских дошкольных заведениях обучение и воспитание безоплатное (Великая Британия (частично), Германия). В Германии, кроме того, законом гарантированную поддерэкку альтернативных дошкольных заведений, кроме частных. В Республике Польша, в Финляндии, Швейиарии государство уделяет много внимания дочкольным учебным заведениям.

В странах ЕС при осуществлении воспитания и обучения в дошкольных учебных заведениях применяются подходь:: дифференцированный, индивидуальный, творческий; используется система Монтессори.

Ключевые слова: структура системы дошкольного образования, Великая Британия, страны $E C$, общие признаки, разные подходы к подготовке детей к школе в разных странах, подходы.

IVANOVA V. V. Structure of the preschool education system in the united kingdom and EU countries (France, Germany, Finland, Poland, Switzerland).

The article deals with the features of the structure of modern preschool education in Great Britain and the EU countries (France, Germany, Finland, Poland, Switzerland).

Along with the peculiarities of the pre-school education system in different countries, common signs have been identified.

Different approaches to preparing children for school in different countries have been clarified (using different forms of integration of kindergartens and primary schools; performing the function of pre-school degree: preparatory groups or classes at kindergartens or primary schools (in Germany); preschool groups for children (in Finland, Denmark); zero classes at schools or preparatory groups in kindergartens (in Poland); funding is different: public and private pre-school education (free of charge) (United Kingdom (partially), Germany). In Germany, in addition, the law guaranteed support of alternative pre-schools except private. In Poland, Finland, Switzerland, the state pays much attention to pre-schools.

In the EU countries, the following approaches are used in the education and training of preschool institutions: differentiated, individual, creative; the Montessori system is used.

Keywords: preschool education system structure, United Kingdom, EU countries, common features, different approaches to preparing children for school in different countries, approaches. 